\title{
Freezing Tolerance of Three St. Augustinegrass Cultivars as Affected by Stolon Carbohydrate and Water Content
}

\author{
F.P. Maier and N.S. Lang \\ Department of Horticulture, Louisiana Agricultural Experiment Station, Louisiana State Univ. Agricultural \\ Center, Baton Rouge, LA 70803 \\ J.D. Fry \\ Department of Horticulture, Forestry, and Recreation Resources, Kansas State Univ., Manhattan, KS \\ 66506
}

Additional index words. cold hardiness, nonstructural carbohydrates

\begin{abstract}
Little is known about intraspecific variability in St. Augustinegrass [Stenotaphrum secundatum (Walt.) Kuntze] freezing tolerance and the physiological factors that may influence survival. Stolons of field-grown 'Raleigh', 'Floratam', and FX-332 St. Augustinegrass were sampled between October and March in 1990 to 1991 and 1991 to 1992 to measure freezing tolerance, nonstructural carbohydrates, and water content. Stolons were exposed to temperatures between 1 and $\mathbf{- 8 C}$ in a freezer, and regrowth was evaluated in the greenhouse. Generally, freezing tolerance of 'Raleigh' > 'Floratam' $=$ FX-332. 'Raleigh' exhibited $>60 \%$ survival in December and January, while survival of 'Floratam' and FX-332 was $<20 \%$. 'Raleigh' was the only cultivar that acclimated, as indicated by a $75 \%$ increase in survival between October and December 1990. Starch and sucrose were the primary storage carbohydrates extracted from stolons, but neither was correlated with freezing tolerance. A negative $(r=-0.80)$ correlation was observed between 'Raleigh' survival and stolon water content between January and March 1991. Reduced water content in 'Raleigh' stolons during winter months may contribute to acclimation.
\end{abstract}

St. Augustinegrass is a popular warm-season turfgrass used in landscapes throughout the warm-humid regions of the southeastern United States. It is the least freezing-tolerant of the warm-season turfgrasses (Beard et al., 1980) and is adapted to U.S. Dept. of Agriculture hardiness zones 8, 9, and 10. Severe freezing injury may occur during some winters in zones 8 and 9.

Field trials to determine freezing tolerance of St. Augustinegrass cultivars (Wilson et al., 1977; Beard et al., 1980; 1982; Dudeck, 1990; Engelke, 1985) indicated that 'Floratam' generally exhibits freezing tolerance inferior to that of 'Raleigh' and 'Texas Common'.

St. Augustinegrass cultivars have also been exposed to freezing temperatures in a controlled environment to determine freezing tolerance. Common St. Augustinegrass was killed after a 16-h exposure to $-4.4 \mathrm{C}$ (Reeves and McBee, 1972). Fry et al. (1991) reported lethal temperatures for 'Floratam' to vary monthly from -6.1 to $-5.3 \mathrm{C}$ between December and March in Louisiana. In contrast, Murdoch et al. (1990) reported that 'Floratam' nodes from actively growing turf were killed following exposure to $-4 \mathrm{C}$.

Nonstructural carbohydrates may influence turfgrass freezing tolerance by serving as osmotic buffers and food reserves (Levitt, 1980). As osmotic buffers, nonstructural carbohydrates may prevent lethal protoplast dehydration during intercellular ice formation. As food reserves, nonstructural carbohydrates are utilized for respiration during dormancy and to resume growth in the spring. The relationship between nonstructural carbohydrates and freezing tolerance has been studied in some warm-season turfgrasses.

Received for publication 6 Sept. 1993. Accepted for publication 9 Dec. 1993. Paper no. 93-28-7244 of the Journal Series, Louisiana Agricultural Experiment Station. (Baton Rouge, La.) Contribution no. 93-463-J of the Kansas Agricultural Experiment Station (Manhattan, Kan.). The cost of publishing this paper was defrayed in part by the payment of page charges. Under postal regulations, this paper therefore must be hereby marked advertisement solely to indicate this fact.
Starch and sucrose increased during fall acclimation in bermudagrass [Cynodon dactylon (L.) Pers.]; however, freezing tolerance did not appear to be related to carbohydrate levels during the acclimation period (Dunn and Nelson, 1974). An increase in total nonstructural carbohydrates was observed during fall hardening in 'Meyer' zoysiagrass (Zoysia japonica Steud.) until a maximum level of $50 \mathrm{mg} \cdot 100 \mathrm{mg}^{-1}$ dry weight occurred in December (Rogers et al., 1975). This suggests that high levels of nonstructural carbohydrates may have contributed to the superior freezing tolerance of 'Meyer'. Centipedegrass [Eremochloa ophiuroides (Munro) Hack.] exhibited an increase in stolon sucrose level during fall acclimation, and this was positively correlated with increased freezing tolerance in acclimated turf (Fry et al., 1993).

Starch and sucrose were the primary storage carbohydrates extracted from 'Floratam' St. Augustinegrass stolons (Fry et al., 1991). Between October and March, starch levels ranged from 7.7 to $12.4 \mathrm{mg} \cdot 100 \mathrm{mg}^{-1}$ dry weight, while sucrose levels ranged from 2.4 to $5.7 \mathrm{mg} \cdot 100 \mathrm{mg}^{-1}$ dry weight. 'Floratam' freezing tolerance varied by $\approx 1 \mathrm{C}$ between December and March and no correlation was observed between survival and carbohydrate level or composition. The potential role of nonstructural carbohydrates in freezing tolerance of St. Augustinegrass cultivars other than 'Floratam' is not known.

In several cool-season grasses, the most freezing-tolerant cultivars had low crown water content, and the least freezing-tolerant cultivars had high crown water content (Beard, 1965). An increase in tissue water content increases ice formation and may result in greater damage to the protoplast. The potential relationship between stolon water content and freezing tolerance in St. Augustinegrass cultivars is unknown.

The objectives of this study were to determine the freezing tolerance of 'Floratam', 'Raleigh', and FX-332 St. Augustinegrass and evaluate the potential contribution of stolon nonstructural carbohydrate and water content to freezing tolerance. 


\section{Materials and Methods}

'Raleigh', 'Floratam', and FX-332 St. Augustinegrass stolons were sampled from the field monthly between October 1990 and March 1991 and between October 1991 and March 1992 to determine freezing tolerance, carbohydrate composition, and water content. These cultivars were selected from the National Turfgrass Evaluation Program St. Augustinegrass Test established in 1990 at the Burden Research Plantation in Baton Rouge, La. 'Raleigh' and 'Floratam' are commercially available. FX-332 is an experimental selection from the University of Florida, Fort Lauderdale Research and Education Center. Turfgrass was established on an Olivier silt loam (fine-silty, mixed, thermic aquic, Fragiudalf) and received $49 \mathrm{~kg} \mathrm{~N} / \mathrm{ha}$ in April and July of each year. Turf was mowed at $6 \mathrm{~cm}$ once weekly during active growth, and when rainfall was not adequate, irrigation was used to apply $3 \mathrm{~cm}$ of water weekly.

Before sampling, turf color was rated visually on a $0 \%$ to $100 \%$ scale, where $0=$ completely brown and $100=$ completely green . All cultivars exhibited similar turf color and growth activity on all sampling dates. Sampling dates, turf color, and plant growth status were as follows: 16 Oct. 1990 (75\% green, active), 26 Nov. 1990 (75\% green, active), 12 Dec. 1990 (35\% green, dormant), 23 Jan. 1991 (25\% green, dormant), 11 Feb. 1991 (65\% green, dormant), 19 Mar. 1991 (80\% green, active), 1 Oct. 1991 (95\% green, active), 12 Nov. 1991 (25\% green, dormant), 16 Dec. 1991 (25\% green, dormant), 15 Jan. 1992 (25\% green, dormant), 21 Feb. 1992 (35\% green, active), and 13 Mar. 1992 (75\% green, active). Actively growing turf exhibited leaf elongation over the few days before sampling, while dormant turf did not. Weekly maximum and minimum mean temperatures were recorded (Fig. 1).

Freezing tolerance. Stolons with roots and leaves intact from

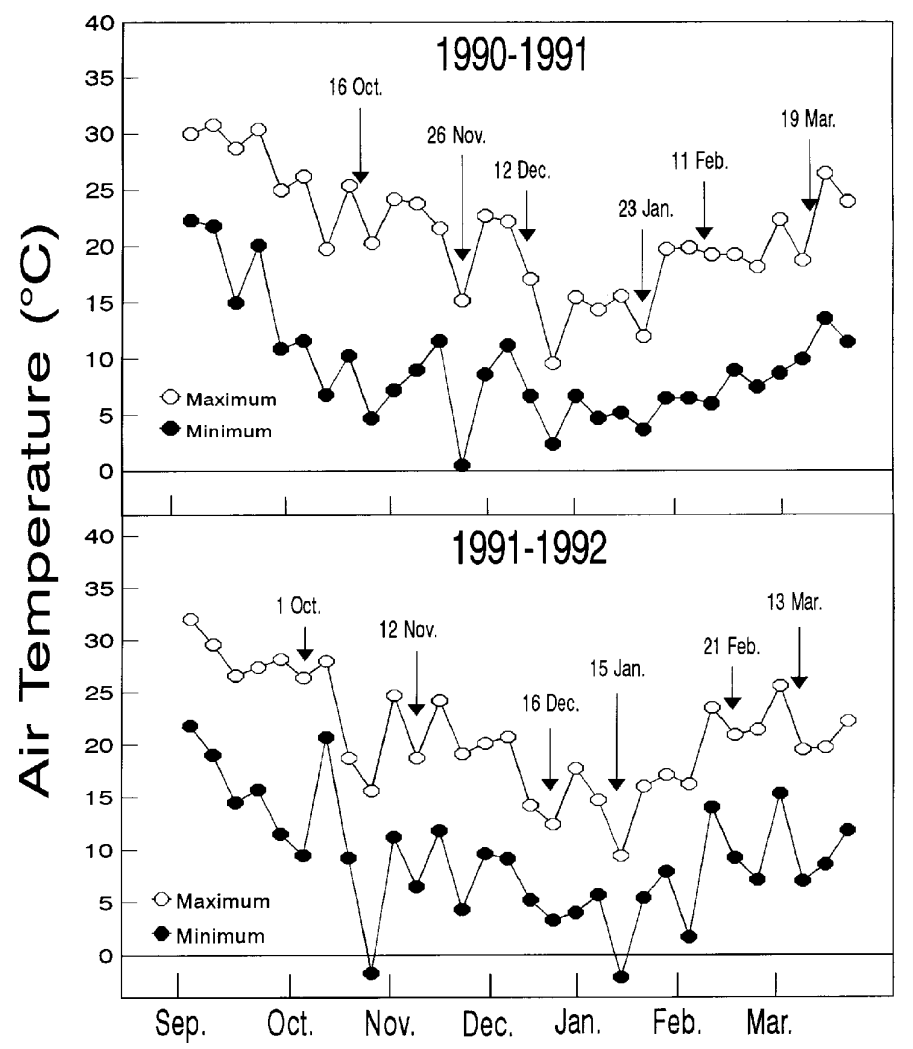

Fig. 1. Weekly minimum and maximum temperature means for 1990 to 1991 and 1991 to 1992 at Baton Rouge, La. Arrows indicate stolon sampling dates. each of the three cultivars were separated into $15-\mathrm{cm}$-long segments with four nodes and washed with tap water. Ten stolons were placed in individual plastic resealable bags $(27 \mathrm{~cm} \times 28 \mathrm{~cm})$. Each bag was considered a replicate, with three replicates included for each treatment temperature $\times$ cultivar combination. Bags were randomly placed in a low-temperature incubator (model C1213; Curtin Matheson Scientific, Houston) with thermocouples inserted in random bags to monitor temperature. Incubator temperature remained at $1 \mathrm{C}$ overnight. The following day, chamber temperature was reduced $2 \mathrm{C} / \mathrm{h}$. Three replicate bags of each cultivar were removed following $1 \mathrm{~h}$ exposure to $-2,-4,-6$, and $-8 \mathrm{C}$. A $1 \mathrm{C}$ treatment was used as a control. Following temperature treatments, stolons were placed in a $1 \mathrm{C}$ incubator to thaw overnight. Thawed stolons were planted in a 1 peat : 1 perlite medium, placed in a greenhouse (mean maximum/minimum air temperature of $27 \mathrm{C}$ and $18 \mathrm{C}$, respectively), and watered as needed to prevent drought stress. Stolons were harvested after 4 to 6 weeks. Surviving nodes were those that were green and turgid. Most, but not all, of these nodes exhibited shoot regrowth. Survival was expressed as a percentage where node survival $(\%)=$ no. of surviving nodes/total nodes $\times 100$. Data were subjected to analysis of variance (ANOVA), and means were separated using the Waller-Duncan $\mathrm{k}$ ratio $t$ test $(\mathrm{k}=100 ; P \approx 0.05)$.

Nonstructural carbohydrates. After severing roots and leaves, stolons were washed with tap water and freeze-dried. Three replicates of freeze-dried material were ground to pass through a 20-mesh screen. One 200-mg sample was weighed from each replicate. Soluble sugars were extracted three times by boiling each sample for $5 \mathrm{~min}$ in $3 \mathrm{ml} \mathrm{80 \%} \mathrm{ethanol.} \mathrm{After} \mathrm{each} \mathrm{extraction}$ the sample was cooled and centrifuged, and the supernatant was decanted. Pellets remaining after ethanol extraction were used to determine starch concentration. Supernatant from each extraction was combined and dried using an Evapo-Mix (Bulcher Instruments, Fort Lee, N.J.). Dried samples were solubilized in $80 \%$ ethanol to a 2-ml volume. A high-performance liquid chromatography system (Fry et al., 1993) was used to analyze samples. Sugars were identified and quantified based on retention times and area under the peak for the following standards (Sigma Chemical): $0.1 \%$ fructose, $0.1 \%$ glucose, $0.2 \%$ sucrose, and $0.1 \%$ maltose.

Remaining starch pellets were suspended in $1 \mathrm{ml} 0.2 \mathrm{M} \mathrm{KOH}$ and boiled for $30 \mathrm{~min}$. Samples were cooled and $\mathrm{pH}$ adjusted to 5.5 using acetic acid. Amyloglucosidase was added to digest starch to glucose. Digestion was stopped after $1 \mathrm{~h}$ by submerging samples in boiling water. Starch levels were determined enzymatically by detecting glucose equivalents. This was accomplished by using a reaction mixture that contained $200 \mathrm{~mm}$ Hepes- $\mathrm{NaOH}$ buffer $(\mathrm{pH}$ 8.0), $10 \mathrm{~mm} \mathrm{MgCl}_{2}, 10 \mathrm{~mm}$ DTT, 2 mм ATP, 2 mм NADP, 2 units hexokinase, and 2 units of glucose-6-phosphate dehydrogenase. Glucose concentrations were measured by detecting the reduction of $\mathrm{NADP}^{+}$using a spectrophotometer (model Lambda 3; PerkinsElmer Corp., Oak Brook, Ill.) and comparing with known standards. Simple correlation analysis was run to determine the relationship between concentration of total nonstructural carbohydrates (TNC), starch, and sucrose levels and node survival at -4 and $-6 \mathrm{C}$ between dates when turf was dormant and actively growing.

Water content. Stolons were prepared as described for carbohydrate analysis and divided into three replicates of $\approx 20 \mathrm{~g}$. Tissue was weighed (fresh weight), dried at $60 \mathrm{C}$ for $48 \mathrm{~h}$ and weighed again (dry weight). Water content (WC) was calculated as WC $(\%)=$ fresh weight-dry weight/ fresh weight $\times 100$. Data were subjected to ANOVA and means were separated using the Waller-Duncan $\mathrm{k}$ ratio $t$ test $(\mathrm{k}=100 ; P \approx 0.05)$. Simple correlations were 


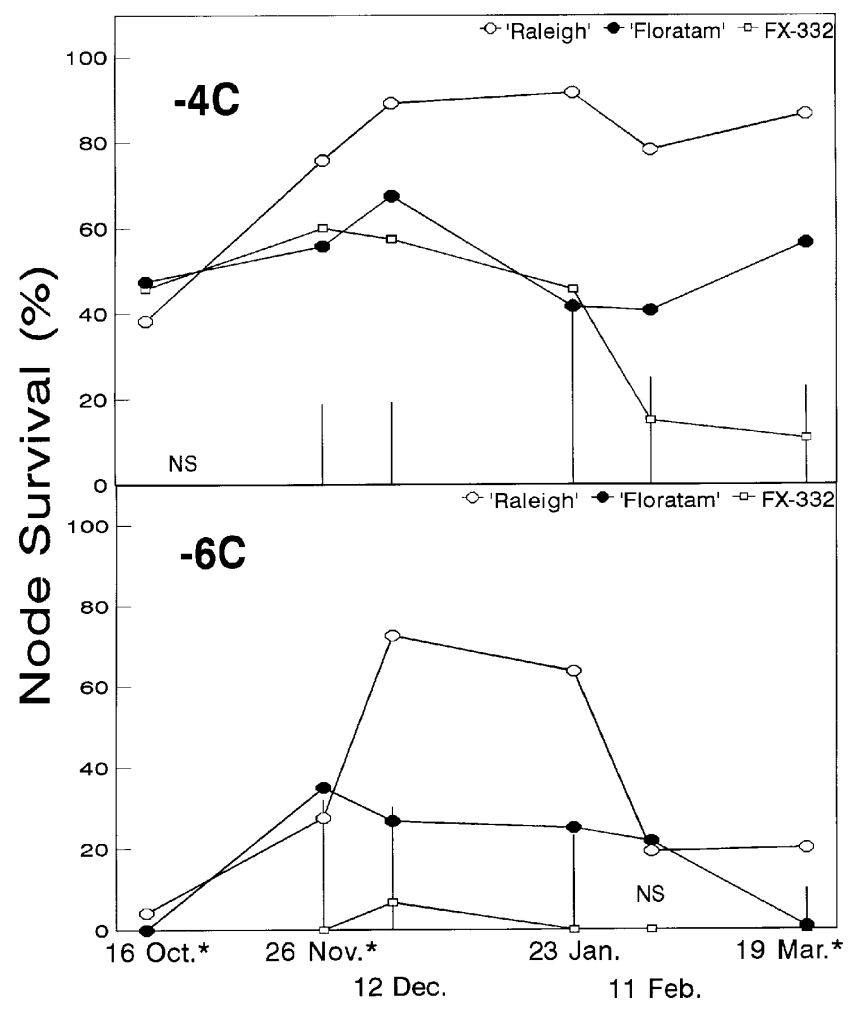

Fig. 2. Node survival of 'Raleigh', 'Floratam', and FX-332 St. Augustinegrass after exposure to $-4 \mathrm{C}$ or $-6 \mathrm{C}$ in 1990 to 1991 at Baton Rouge, La. Vertical bars represent minimum significant difference determined by the Waller-Duncan $\mathrm{k}$ ratio $t$ test $(\mathrm{k}=100 ; P \approx 0.05)$. Ns indicates no significant difference. Asterisks denote active growth.



Fig. 3. Node survival of 'Raleigh', 'Floratam', and FX-332 St. Augustinegrass after exposure to $-4 \mathrm{C}$ or $-6 \mathrm{C}$ in 1991 to 1992 at Baton Rouge, La. Vertical bars represent minimum significant difference determined by the Waller-Duncan $\mathrm{k}$ ratio $t$ test $(\mathrm{k}=100 ; P \approx 0.05)$. Ns indicates no significant difference. Asterisks denote active growth. completed between changes in WC and node survival at critical temperatures between months when turf was dormant and actively growing.

\section{Results and Discussion}

Freezing tolerance. A significant cultivar $\times$ temperature $\times$ year interaction was observed; therefore, data from each year are presented separately. Greatest differences in node survival occurred after exposure to -4 or $-6 \mathrm{C}$ in each year, and cultivar mean separations are presented at these temperatures (Fig. 2).

In 1990 to 1991, 'Raleigh' St. Augustinegrass exhibited better node survival than 'Floratam' or FX-332 after exposure to $-4 \mathrm{C}$ on 12 Dec., 23 Jan., 11 Feb., and 19 Mar. 'Floratam' node survival at $-4 \mathrm{C}$ was superior to that of FX-332 on 11 Feb. and 19 Mar. When stolons were exposed to -6C during 1990 to 1991, 'Raleigh' node survival exceeded that of 'Floratam' by $46 \%$ and FX-332 by $66 \%$ on 12 Dec. 'Raleigh' also exhibited node survival superior to that of other cultivars on 23 Jan.

During 1991 to $1992,>80 \%$ 'Raleigh' node survival was observed after exposure to $-4 \mathrm{C}$ on all sampling dates (Fig. 3). 'Raleigh' node survival was superior to that of 'Floratam' after treatment at $-4 \mathrm{C}$ on 16 Dec., 15 Jan., and 13 Mar. Fewer than $25 \%$ of 'Floratam' and FX-332 nodes survived $-6 \mathrm{C}$ on all sampling dates in 1991 to 1992. 'Raleigh' node survival was better than that of other cultivars after exposure to $-6 \mathrm{C}$.

'Raleigh' node survival at $-6 \mathrm{C}$ during 1990 to 1991 clearly demonstrated that it acclimates to low temperatures (Fig. 2). Node survival on 12 Dec. was $75 \%$ greater than on 16 Oct. Between these sampling dates, weekly maximum and minimum temperature means dropped by $\approx 5 \mathrm{C}$ (Fig. 1). Greater than $60 \%$ of 'Raleigh' nodes survived $-6 \mathrm{C}$ on 23 Jan. By 11 Feb., 'Raleigh' had deacclimated and node survival did not differ from that of other cultivars exposed to $-6 \mathrm{C}$. De-acclimation between 23 Jan. and 11 Feb. appeared to be temporally related to a general increase in mean weekly temperature (Fig. 1). 'Raleigh' exhibited a 32\% increase in node survival after exposure to $-6 \mathrm{C}$ between $1 \mathrm{Oct}$. and 12 Nov. 1991. After 16 Dec., a steady decline in 'Raleigh' node survival was observed until 13 Mar. when a slight increase occurred (Fig. 3). In southern Louisiana, good freezing tolerance is most important in December and January when lowest temperatures occur. Nevertheless, nonacclimated 'Raleigh' exhibited better freezing tolerance than 'Floratam' or FX-332 during October, November, February, and March.

'Floratam' exhibited slight acclimation during 1990 to 1991, as indicated by a $35 \%$ increase in node survival at $-6 \mathrm{C}$ between 16 Oct. and 26 Nov. (Fig. 2). Node survival remained near $25 \%$ until 19 Mar., when no nodes survived -6C. During 1991 to 1992, a similar acclimation pattern was not observed in 'Floratam' (Fig. $3)$.

Fry et al. (1991) reported little change in 'Floratam' freezing tolerance between December and March in Louisiana. In Florida, researchers reported that nodes from actively growing 'Floratam' did not survive -4C when sampled in February (Murdoch et al., 1990). Results of the present study indicate that 'Floratam' may have only a slight capacity to acclimate to freezing temperatures.

FX-332 exhibited no acclimation to freezing temperatures in either year.

Nonstructural carbohydrates. Primary storage carbohydrates extracted from stolons of all cultivars were starch and sucrose (Fig. 4 and 5). Glucose, fructose, and maltose were extracted in amounts $<1 \mathrm{mg} \cdot 100 \mathrm{mg}^{-1}$ dry weight, and data are not presented. Starch levels ranged from a low of $4.9 \mathrm{mg} \cdot 100 \mathrm{mg}^{-1}$ dry weight for 


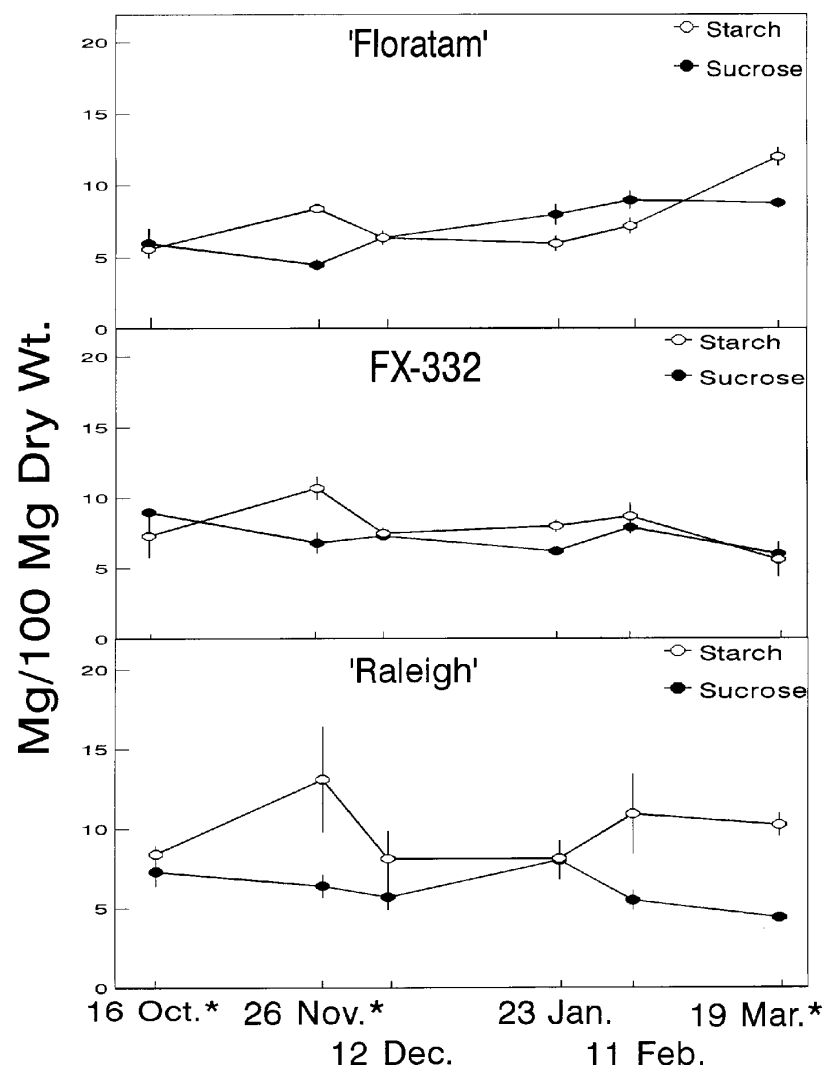

Fig. 4. Stolon starch and sucrose concentrations in 'Floratam', FX-332, and 'Raleigh' St. Augustinegrass during 1990 to 1991 at Baton Rouge, La. Bars represent the SE. Asterisks denote active growth.

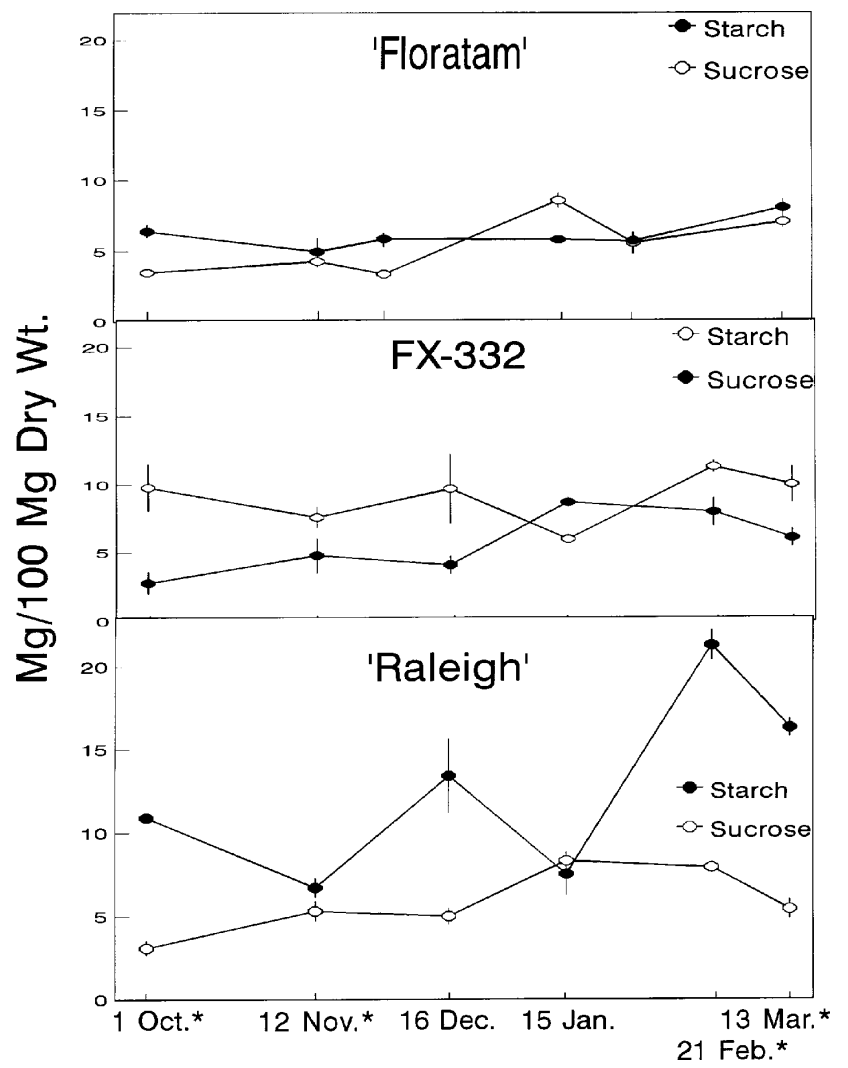

Fig. 5. Stolon starch and sucrose concentrations in 'Floratam', FX-332, and 'Raleigh' St. Augustinegrass during 1991 to 1992 at Baton Rouge, La. Bars represent the SE. Asterisks denote active growth.
'Floratam' on 12 Nov. 1991 to a high of $21.3 \mathrm{mg} \cdot 100 \mathrm{mg}^{-1}$ dry weight for 'Raleigh' on 21 Feb. 1992. No significant correlation was observed between starch level, sucrose level, or total nonstructural carbohydrate (TNC) level and node survival at -4 or $-6 \mathrm{C}$ for any cultivar. The present results for 'Floratam' are similar to those described by Fry et al. (1991), who observed that changes in stolon starch and sucrose levels in 'Floratam' did not influence freezing tolerance. In contrast, centipedegrass stolon sucrose concentration increased $47 \%$ during acclimation in a controlled environment, and was positively correlated with stolon survival (Fry et al., 1993).

Water content. Water content ranged from $67 \%$ to $80 \%$ for 'Raleigh', $75 \%$ to $82 \%$ for 'Floratam', and $76 \%$ to $85 \%$ for FX-332 over all sampling dates (data not shown). A negative correlation $(r$ $=-0.80$ ) was observed between 'Raleigh' node survival at $-6 \mathrm{C}$ and stolon water content between 23 Jan. and 19 Mar. 1991. As stolon water content increased from $73.6 \%$ to $77.7 \%$, node survival decreased from $63.3 \%$ to $20.0 \%$. There were sampling dates when cultivars exhibited no differences in stolon water content, but differed in freezing tolerance. Conversely, there were also dates when freezing tolerance of cultivars differed, but stolon water content did not. Lower stolon water content in acclimated 'Raleigh' may serve a role in acclimation.

Survival of 'Raleigh' St. Augustinegrass, but not 'Floratam', was observed in the field after a winter low temperature of $-15 \mathrm{C}$ in Mississippi (Wilson et al., 1977). Results of the present study indicate that 'Raleigh' has a greater capacity to acclimate to freezing temperatures than 'Floratam' and FX-332 St. Augustinegrass.

\section{Literature Cited}

Beard, J.B. 1965. Direct low temperature injury of nineteen turfgrasses. Mich. Agr. Expt. Sta. Quarterly Bul. 48:377-383.

Beard, J.B., S.M. Batten, and G.M. Pittman. 1980. St. Augustinegrass cultivar characterization. Texas Turf Res. p. 44-47.

Beard, J.B., R.L. Toler, R.L Crocker, and M.P. Grisham. 1982. St. Augustinegrass cultivar update. Texas Turf Res. p. 20-22. Texas Agr. Expt. Sta., Texas A\&M Univ., College Station, Texas.

Dudeck, A.E. St. 1990. St. Augustinegrass performance in north Florida. Turfgrass Res. in Florida. p. 13-17. Inst. of Food and Agr. Sci., Univ. of Florida, Gainesville, Fla.

Dunn, J.H. and C.J. Nelson. 1974. Chemical changes occurring in three bermudagrass turf cultivars in relation to cold hardiness. Agron. J. 66:28-31.

Engelke, M.C. 1985. Winter survival evaluation of St. Augustinegrass genotypes at TAES-Dallas, p. 69-71. Texas Turf Res. Texas Agr. Expt. Sta., Texas A\&M Univ., College Station, Texas.

Fry, J.D., N.S. Lang, and R.G.P. Clifton. 1991. Freezing resistance and carbohydrate composition of 'Floratam' St. Augustinegrass. HortScience 26:1537-1539.

Fry, J.D., N.S. Lang, R.G.P. Clifton, and F.P. Maier. 1993. Freezing tolerance and carbohydrate content of low temperature-acclimated and non-acclimated centipedegrass. Crop Sci. 33:1051-1055.

Levitt, J. 1980. Responses of plants to environmental stresses, p. 67-290. vol. 1. Chilling, freezing, and high temperature stress. 2nd ed. Academic, New York.

Murdoch, C.L., A.E. Dudeck, and C.L. Guy. 1990. Development of a technique for screening St. Augustinegrass for cold tolerance. Turfgrass Res. in Fla. p. 53-62. Inst. of Food and Agr. Sci., Univ. of Florida, Gainesville, Fla.

Reeves, S.A. and G.G. McBee. 1972. Nutritional influences on cold hardiness of St. Augustinegrass (Stenotaphrum secundatum). Agron. J. 64:447-450.

Rogers, R.A., J.H. Dunn, and C.J. Nelson. 1975. Cold hardening and carbohydrate composition of Meyer zoysia. Agron. J. 67:836-838.

Wilson, C.A., J.A. Reinert, and A.E. Dudeck. 1977. Winter survival of St. Augustinegrasses in north Mississippi. Quarterly News Bul. Southern Turfgrass Assn. V. 12:20. 